\title{
Winter hard wheat in Kursk Region
}

\author{
Anna Emelyanova $^{1^{*}}$, and Elena Logvinova ${ }^{1}$ \\ ${ }^{1}$ FSBSI "Federal Agricultural Kursk Research Center" 70b, Karl Marx St., Kursk, 305021, Russia
}

\begin{abstract}
Kursk Federal Agricultural Research Center, together with National Grain Center named after P.P. Lukyanenko, has been studying and selecting hybrid populations, lines and varieties of hard winter wheat since 2012. Since 2017, they have been studied for ecological plasticity and the presence of economically valuable features when cultivating in the Central Chernozem Region (Kursk Region) varieties of winter hard wheat bred by FSBSI "Agricultural Research Center "Donskoy"on the basis of agreements on creative and scientific cooperation. At this stage of research, a large number of seedlings of winter hard wheat were tested, of which the most promising ones were identified. Using highly effective methods of ecological selection and having worked out breeding material in the environmental breeding laboratory of Kursk FARC, research data for 2018-2020. on yield, resistance to creep, overwintering, crop structure (height of plants, number of plants, number of stems, number of productive stems, total bush, productive bush, mass of 1000 grains, length of main spike, number of grains in main spike, weight of grain from one plant) and grain quality, on the basis of which grades and lines of winter hard wheat are evaluated. Over the years of research, weather conditions have developed in a variety of ways. Adverse environmental factors made it possible to better assess the level of adaptability of the studied sorto samples to abiostresses. In this regard an important task of joint breeding, is to increase environmental sustainability, the ability to ensure high stable yields in the soil and climatic conditions of the cultivation region.
\end{abstract}

Keywords: winter hard wheat, breeding, variety, line, crop, structure, overwintering, creeping, adaptability, grain quality, assessment.

\section{Introduction}

In grain crop selection, winter hard wheat is a young crop [1]. And it dates back to the first half of the 20th century. The first varieties were registered in the State Register of Breeding Achievements only in the 50s of the last century. Currently, 28 varieties of winter hard wheat are zoned, mainly in the North Caucasus region. It is, of course, not so much, compared to winter soft and spring hard wheat. Until about the 70 s of the XX century, our country occupied one of the leading places in the gross yield of hard wheat in the world, and now occupies only 13th place, the leadership in this area remains with Canada.

The situation in our country is such that we cannot provide our domestic market with this crop that is valuable to producers.

With all this, expanding the range of cultivating winter hard wheat could undoubtedly improve the situation. The annual harvest of hard wheat grains is about 700 thousand tons.

Hard wheat occupies the second place in importance after soft wheat, since its grain is a particularly valuable raw material for the production of high-quality pasta, cereals, dietary nutrition, spaghetti $[2,3]$. So why winter hard wheat? Here it has a number of advantages over the spring form; firstly, a more developed root system and early maturation, which makes it possible to better tolerate drought through the use of autumn-winter precipitation, and secondly, high productivity.
Despite the successes achieved in the selection of winter hard wheat at present, its global gene pool is not large, compared to spring one. Genetic sources for use in selection are often not suitable due to low ecological plasticity. Therefore, the selection process is extended for decades, in connection with which the inclusion of adapted environmentally-plastic material in the selection process becomes of great importance [1].

The main direction for the near future should be recognized selection for wide adaptation, based on giving the varieties frost resistance, drought resistance, resistance to creep. The efficiency of introducing new adaptive varieties, as a rule, exceeds all other agricultural methods and does not require a large material cost. Currently, the variety has become the factor without which it is impossible to implement scientific and technical progress in agriculture and achieve effective development of production and economic stability.

The purpose of the research was to study and isolate a promising selection material of winter hard wheat of environmentally plastic highly productive, biotic and abiotic stress resistant in the soil-climatic conditions of the Central Chernozem Zone (Kursk Region) for further selection work.

\section{Materials and methods}

The study material was varieties and lines of winter hard wheat of selection of FSBSI "National Grain Center

\footnotetext{
*Corresponding author: emeiyanova.a87@mail.ru
} 
named after P.P. Lukyanenko" and FSBSI "Federal Research Center "Donskoy".

The climate of the zone is continental, in terms of providing heat, it belongs to the territory of cultivation of medium-ripe crops, in terms of humidification it is humid. The probability of drought and dry years is $10 \%$, biological activity according to the climate index is mainly average.

In the Environmental Breeding Laboratory of Kursk FARC, crops were located in the fields of a special breeding crop rotation. The predecessor was black fallow.

Field management was typical of the conditions of Kursk Region. The soil of the experimental plot is represented by typical deep chernozem. The content of humus in the arable layer is $6.1 \%$, mobile phosphorus (according to Chirikov method) 15.6, exchangeable potassium (according to Maslova method) $11,3 \mathrm{mg} / 100 \mathrm{~g}$ of soil. The reaction of the soil medium is neutral $(\mathrm{pH} 6.5-$ 7.0).

The research was carried out on the basis of the Laboratories of Ecological Breeding and Seed Production according to the methodology of the State Variety Testing of Crops, using the statistical methods of "Field Experiment Methodology" by B.A. Dospekhov.

In competitive variety testing, sowing of crops was carried out on plots with an area of $10 \mathrm{~m}^{2}$, replication was six-fold. Seeding rate was $5 \mathrm{mln}$. germinating grains per 1 ha. The location of the plots in the first tier was systematic, for the convenience of demonstrating experiments, in the rest plots it was rendomized. A method of sowing was continuous drill with the help of a selection, portion seeder SKS-6-10.

During the experiments, phenological observations were made on the phases: seedlings, tillering, heading, milky ripeness, wax ripeness, complete ripeness. The density of plant standing in seedlings and before harvesting was taken into account, the damage to diseases was recorded: powdery mildew and brown rust. Score assessment of the state of crops by seedlings and before harvesting, resistance to creeping, equalization of stem stand, and productivity of the ear was carried out. After harvesting the breeding plots, the harvest was recorded, in the laboratory conditions plants were analyzed for elements of the harvest structure (height of plants, number of plants, number of stems, number of productive stems, total bushiness, productive bushiness, weight of 1000 grains, length of the main ear, number of grains in the main ear, weight of grain from one plant), equalization and estimation of grain filling. The grain quality analysis was carried out using the Infratecalso analyzer.

\section{Results and Discussion}

The basis for the selection of grain crops in the Federal State Budgetary Scientific Institution "Kursk FARC" is an ecological principle, which, according to the definition is a set of techniques and methods that ensure the creation of varieties and hybrids with maximum and stable productivity in the conditions of the proposed cultivation region. The ecological principle is a highly efficient, less costly and accelerated method of selection: parallel study of the starting material in various ecological environments, creation of genetic diversity and its sharing $[4,5,6,7]$. Ecological plasticity of new varieties, their resistance to limiting factors of the external environment and the ability to form high yields is a priority direction in breeding. Choosing the best crop varieties is the cheapest, most affordable and fastest way to increase crop yields and gross grain yields.

During the years of research, the weather conditions during the vegetation of plants developed in a variety of ways, which made it possible to better assess the ability of the studied varieties and lines to adapt to adverse environmental factors. These are described in more detail in Table 1 below.

In 2018, weather conditions during the overwintering of winter crops developed satisfactorily. The resumption of vegetation was observed at a time close to long-term. Dry wind and dry wind phenomena, in the milky ripening phase, had an adverse effect on the formation of grain crops. With frequent and heavy precipitation, during the period of complete ripeness, conditions have developed for the shattering of grain and its germination in the stand, which negatively affected the quality and productivity of winter crops

Table1. Meteorological conditions of the growing season (according to the weather center "Petrin" of Kursk Region, average for 2018-2020).

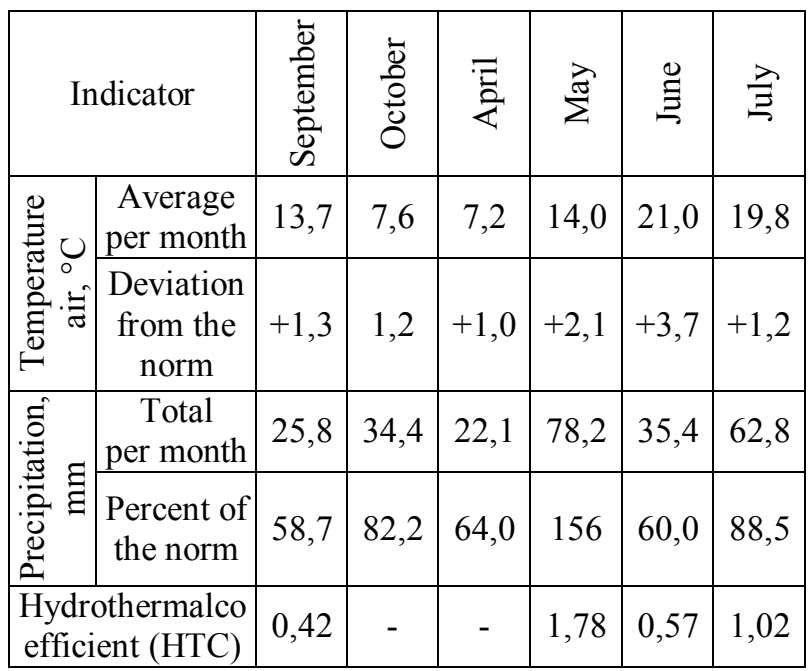

In 2019 at the beginning of development in winter crops, due to lack of moisture in the soil, the crop growth and development were restrained. Moisture availability in the arable soil layer in places decreased to $18-25 \mathrm{~mm}$. According to the Petrin weather station, a dangerous agrometeorological phenomenon "soil drought" was preserved under winter wheat in the arable layer of soil since the third decade of August.

Satisfactory agrometeorological conditions for overwintering winter crops prevailed. The course of wintering was complicated by a thick snow cover, with a weak freezing of the soil, conditions were formed for the occurrence of fungal diseases and weakening of plants.

The resumption of winter wheat vegetation was noted in time close to long-term. Later plant development was 
1-2 weeks ahead of the average long-term date and maturation occurred 2 weeks earlier.

In 2020, the increased temperature regime and the long ( 3 weeks) absence of effective precipitation in the presowing period led to a decrease in available moisture at the depth of seed embedding, which restrained seed germination and growth processes for 1.5-2 weeks. The rains at the end of September improved the situation. By the time vegetation ceased, winter crops were in the tillering phase. Conditions for overwintering of winter crops were favorable, however, in thawed weather the resting state of the plants was disturbed, which caused nutrient consumption, which in turn weakened the plant. A month earlier than the average long-term period the resumption of vegetation in winter crops was noted (March 5-10). Favorable agrometeorological conditions for grain filling prevailed. During the ripening period of the grain ( 2 decades of July), intensive precipitation with an increase in wind of up to $18 \mathrm{~m} / \mathrm{s}$ created conditions for plant lodging and shattering of grain of the ripened crop.

Winter hard wheat is more vulnerable to negative impacts of the winter environment, which is the main problem in our region with severe conditions for wintering winter crops, unlike the more southern North Caucasus and Lower Volga regions. However, climate change, breeding for winter resistance and selection of adapted material directly in the area of the intended cultivation cannot but inspire optimism that this problem will soon be solved. Figure 1 shows the overwintering level of the selected variety samples for 2018-2021.

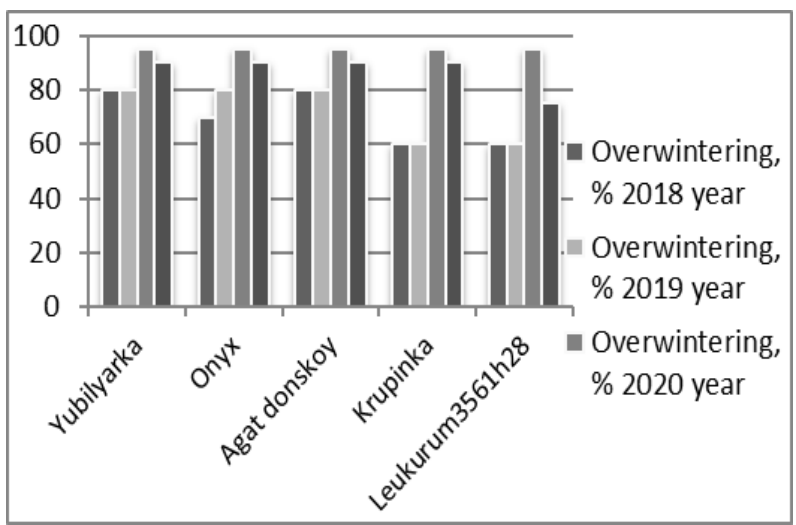

Fig 1. Winter hard wheat overwintering level by year

Also a big problem in the selection of winter hard wheat is its tendency to lodging, Figure 2.

In recent years, due to strong winds and showers in summer, most of the varieties of winter hard wheat lodge. Therefore, increasing the resistance of the material to lodging is of great importance in the selection of hard winter wheat. Unfortunately, this problem is not fully solved by shortness and semi-dwarfishness. Therefore, it is necessary to select breeding material with unlodging strong straw, shortened internodes, filled straw, etc.

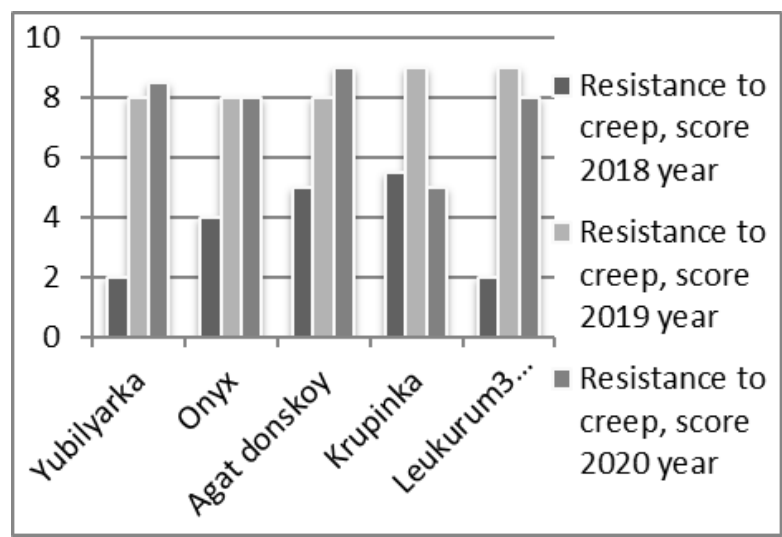

Fig 2. Resistance to lodging of winter hard wheat

Currently, in Central Chernozem Region there are no varieties of winter hard wheat allowed for cultivation, which explains the lack of a standard in the experiment.

The fundamental role of breeding and variety in increasing gross grain yields is well known. Among various agricultural practices the variety accounts for $30 \%$ of the increase in yield, and in extreme weather conditions (severe winters, droughts, disease epiphytotia), the variety has a decisive role.

The yield of the isolated varieties and lines of winter hard wheat, in the nursery of competitive variety testing, was on the average at about the same level over the years of the study and amounted to 5.16-5.60 t/ha. Depending on agrometeorological conditions in the growing season plant yields ranged from 3.72 t/ha to 7.25 t/ha, Table 2 .

Table 2. Yield of winter hard wheat grains 2018-2020 years

\begin{tabular}{|c|c|c|c|c|}
\hline \multirow{2}{*}{ Variety, line } & \multicolumn{4}{|c|}{ Yield t/ha } \\
\cline { 2 - 5 } & $\begin{array}{c}2018 \\
\text { year }\end{array}$ & $\begin{array}{c}2019 \\
\text { year }\end{array}$ & $\begin{array}{c}2020 \\
\text { year }\end{array}$ & average \\
\hline Yubilyarka & 4.75 & 5.14 & 6.47 & 5.45 \\
\hline Onyx & 5.10 & 4.28 & 6.80 & 5.39 \\
\hline Agat Donskoy & 5.32 & 4.53 & 6.95 & 5.60 \\
\hline Krupinka & 3.72 & 4.53 & 7.25 & 5.16 \\
\hline $\begin{array}{c}\text { Leukurum356 } \\
\text { 1h28 }\end{array}$ & 4.83 & 4.43 & 7.19 & 5.48 \\
\hline LSD $_{05}$ & 1,5 & 0,9 & 1,8 & - \\
\hline
\end{tabular}

In 2018 , the yield of isolated variety samples was 3.72-5.32 t/ha. The highest productivity was noted in the Agat Donskoy variety. In 2019 the yield of varieties and lines of winter hard wheat was approximately at the same level of 4.28-5.14 t/ha. In 2020 favorable weather conditions of overwintering, as well as of the entire growing season of plants, made it possible to harvest the largest crop during the studies of $6.47 \mathrm{t} / \mathrm{ha}$ (Yubilyarka variety) to $7.25 \mathrm{t} / \mathrm{ha}$ (Krupinka variety). It should also be noted that the yield of the Leukurum $3561 \mathrm{~h} 28$ line in 2020 was $7.19 \mathrm{t} / \mathrm{ha}$ and an average of $5.48 \mathrm{t} / \mathrm{ha}$ over the years of the study.

The main way to increase the productivity of grain crops is the creation and introduction into production of highly productive varieties that combine important economic and biological features in one plant. 
Based on the structural analysis of varieties and lines of winter hard wheat, we can judge the presence of economically valuable features in the isolated variety samples. Based on the weight of 1000 grains from 45.1 to $51.9 \mathrm{~g}$, on the average for $2018-2020$, it can be concluded that the varieties and the line of winter hard wheat have a fairly large filled grain, Table 3.

Table 3. Structural analysis of winter hard wheat (average for 2018-2020).

\begin{tabular}{|c|c|c|c|c|c|}
\hline \multirow[b]{2}{*}{ Variety, line } & \multirow[b]{2}{*}{ 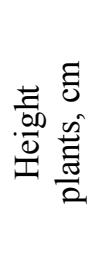 } & \multirow[b]{2}{*}{ 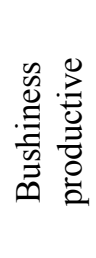 } & \multicolumn{2}{|c|}{ Ear Analysis } & \multirow[b]{2}{*}{$\begin{array}{l}\text { Weight } \\
\text { of } 1000 \\
\text { grains, }\end{array}$} \\
\hline & & & $\begin{array}{l}\text { हే } \\
\text { Eే } \\
\tilde{E} \\
\tilde{\Xi}\end{array}$ & 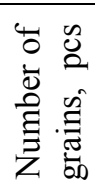 & \\
\hline Yubilyarka & 94,0 & 3,5 & 6,5 & 39 & 49,9 \\
\hline Onyx & 86,7 & 2,7 & 6,0 & 41 & 45,2 \\
\hline AgatDonskoy & 95,7 & 3,0 & 5,0 & 38 & 46,6 \\
\hline Krupinka & 87,8 & 3,4 & 6,0 & 39 & 51,9 \\
\hline $\begin{array}{c}\text { Leukurum35 } \\
61 \mathrm{~h} 28\end{array}$ & 78,5 & 2,8 & 5,5 & 38 & 49,0 \\
\hline
\end{tabular}

It is also possible to note the ability of plants to form a grain-rich ear of 38-41 grains, on the average. A large role in the formation of yield is played by productive bushiness, as it compensates for the loss of plants, due to adverse environmental effects as well.

Productivity is an important sign of the variety, which is assigned the paramount importance in the selection work. It is due to a different combination of quantitative features, which are the result of a complex interaction of the genotype and the external environment. Highly productive varieties should successfully withstand stressors, make the most of favorable conditions and maintain a stable level of yield.

The growing season of the isolated variety samples averaged 286-300 days over the study years. The isolated varieties and line are characterized by resistance to major leaf diseases.

The quality indicators of winter hard wheat grains are important for producers. This is due to the production of high-quality products from purchased raw materials (cereals, pasta), and for farmers the high quality of grown grain will make it possible to achieve the greatest profit.

Protein content is an important property. According to the amount of protein in the grain, an amount of gluten is also formed. Gluten in pasta performs important functions as a lubricant that gives the mass of starch grains fluidity, and a binder that binds starch grains into a single test mass.

The results of the grain quality analysis of the studied varieties and the winter hard wheat line are shown in Table 4 and show a high level of protein in the grain.

Table 4. Grain quality indicators of winter hard wheat (average for 2018-2020).

\begin{tabular}{|c|c|c|c|c|c|}
\hline Variety, line & 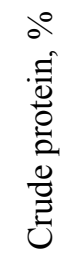 & 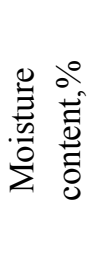 & 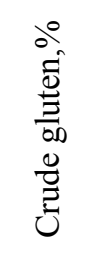 & 殅 & 官 \\
\hline Yubilyarka & 14,0 & 11,2 & 24,0 & 105,4 & III \\
\hline Onyx & 14,7 & 11,4 & 24,4 & 109,0 & III \\
\hline AgatDonskoy & 14,9 & 11,3 & 25,36 & 105,6 & III \\
\hline Krupinka & 13,9 & 10,4 & 20,0 & 98,1 & II \\
\hline $\begin{array}{c}\text { Leukurum } \\
3561 \mathrm{~h} 28\end{array}$ & 14,4 & 12,0 & 19,2 & 104,8 & II \\
\hline
\end{tabular}

\section{Conclusion}

Studying the adaptive properties of winter hard wheat samples makes it possible to isolate plastic, adaptive and stable varieties, as well as to determine the norm of their reaction to limiting growing conditions.

Increasing the production of hard wheat grains, the main raw material for high-quality pasta, is one of the important and so far unresolved problems, but based on our research, one of the solutions to this problem may be to expand the areas of cultivation of winter hard wheat in non-traditional areas of its cultivation. Winter hard wheat has prospects for cultivation in Kursk Region

Varieties and lines of winter hard wheat studied for 2018-2020 years in the Federal State Budgetary Scientific Institution "Kursk FARC" showed themselves by the main economic and valuable features (yield, raw protein content in grain, elements of the yield structure), by the level of adaptability to the stress effects of the external environment rather promising and are of interest for further selection work.

The work was carried out within the framework of the state tasks of FSBSI«Federal Agricultural Kursk Research Center» on topic No. 0632-2019-0011

\section{References}

1. A.A. Mudrova, A.S. Yanovsky, Grain econ. Russia. 1(43) (2016)

2. N.E. Samofalova, N.P. Ilichkina, M.A. Avramenko, O.A. Dubinin, T.G. Derova, Grain econ. Russia. 6(48). P. $42-47$ ( 2016)

3. Ch. Loyce *, J.M Meynard, Indust. Crops \& Prod. France, 6 (1997)

4. A.V. Kilchevsky, L.V. Khotyleva, Ecological plant breeding, Minsk: Tehnalogiya (1997)

5. S.I. Grib, Vesci Nat. Acad. Sci. Belarus. Ser. Agrar. Sci. (2013)

6. 10 Hafiz Ghulam Muhu-Din Ahmed, Abdus Salam khan, LI Ming-ju, Sultan Habibullah Khan,

Muhammad Kashif, J. Integr. Agr. China, Pakistan. 18(11) (2019)

7. M. V. Lopez, M Vega, R. Gracia, A. Claver Industr. Crops \& Prod., Spain 159 (2021) 